\title{
Structure and DFT Calculation of fac-Tris(3-methyl-2-phenylpyridine)Ir(III) Complex
}

\author{
Sung Ouk Jung, Youngjin Kang, Hyung-Sun Kim, Yun-Hi Kim, Kiyull Yang,; and Soon-Ki Kwon \\ Department of Pohmer Science \& Engineering and Engineering Research /nstitute \\ "Department of Chemistry Education, Gyeongsang National Liversity, Chinju 660-70/, Korea \\ Received.hly 16, 2003
}

Key Words : Electrophosphorescence, X-ray structure, DFT calculations, $\operatorname{lr}(m p p)_{\mathrm{s}}$ (mpp - n-methyl-2phenylpyridine)

Luminescent transition metal complexes have attracted much attention recently due to their potential applications to photochemistry, organic light-emitting diodes (OLEDs) and chemical sensors for small molecules $\left(\mathrm{O}_{2}\right)$.' In particular. phosphorescent metal complexes have been considered to be promising materials because of their ability to achieve maximum internal quantum efficiency, nearly $100 \%$, as well as high external quantum efficiency in OLEDs. ${ }^{2}$ For example, $d$-block heavy metal complexes incorporating $p p v$ (2-phenylpyridine) derivatives, such as those of $\operatorname{Ir}([1])$ and Pt(ll), have shown to be highly efticient electrophosphorescent emitters in OLEDs. ${ }^{3}$ Among these transition metal complexes, Ir complexes are regarded as the most effective materials in OLEDs, in which they show a high thermal stability, a shorter life time in excited states than that of other transition metal complexes, and tunable emission energy in the region of blue to red through the modification of $\mathrm{C}^{\mathrm{N}} \mathrm{N}$ ligands and/or introduction of a variety of electron donor/ acceptor in the ppy ring. ${ }^{-}$Recently. Forrest et al. has reported that the effect of methyl substitution in Alq; showed different thermal stability and electroluminescent properties by the position of methylation in 8-quinolinol ligand. Based on this result, we expect that luminescent properties and ${ }^{3}$ MLCT states in [r(ppy); are affected by even a small methyl substituent.

Of these $\operatorname{Ir}(m p p)_{3} \quad\left(m p p^{-}\right.$n-methyl-2-phenylpyridine) derivatives, the structural characterization and DFT calculation of tris(3-methyl-2-phenylpyridine) [r(ll]) complex as a representative are carried out for the following reason: Methyl substituent at the 3 position of the pyridine group leads to a non co-planar arrangement between the phenyl and pyridine ring. which may influence the MLCT excited state and the intermolecular interactions in solid states.

The methyl substituted ppy ligand was synthesized according to Suzuki coupling." by the reaction of 2-bromo3-methylpyridine with a phenylboronic acid in the presence of $\mathrm{K}_{2} \mathrm{CO}_{3}$ and $\mathrm{Pd}\left(\mathrm{PPh}_{3}\right)_{1}$ catalyst, as shown in Scheme $\mathrm{I}$. This ligand was obtained in good yields $(-85 \%)$. The complex 1 was synthesized by a slight modification of a previous synthetic methodology reported by Watt $e t a{ }^{7} \mathrm{By}$

"Co-corresponding authors. Soon-Ki Kwon (skwon@nongac. gsnu.ac.kr), Youngjin Kang (kangy $(\hat{\alpha}$ gshp.gsnu.ac.kr)

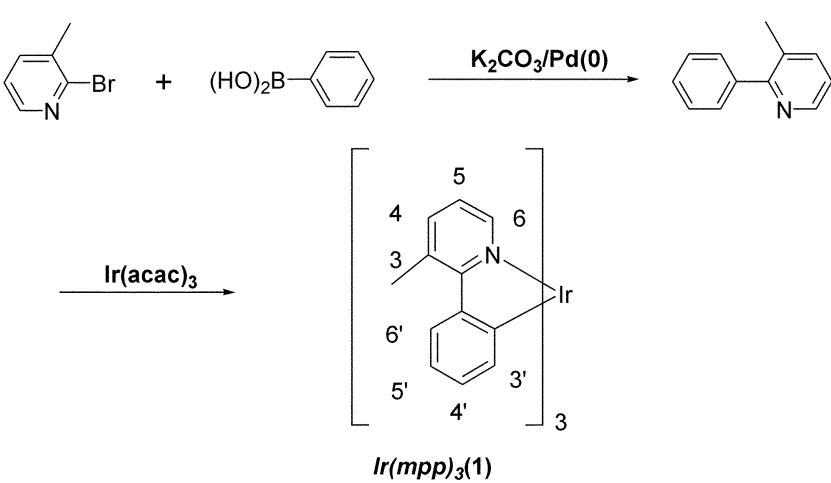

Scheme 1

the reaction of $\operatorname{lr}(\mathrm{acac})_{3}$, with the methyl-substituted at $\mathrm{N}-3$ position in ppy at high temperature (up to $200^{\circ} \mathrm{C}$ ), complex 1 was obtained in a moderate yield. There is a possibility of a formation of two isomers ( $f a c$ and $m e r$ ) during the reaction. ${ }^{8}$ However, we found that facial isomer was formed as a major component at the high reaction temperature even though $m e$-isomers were also formed. The mer-isomers formed were not isolated because of extremely low yields. Complex 1 is very stable up to $300^{\circ} \mathrm{C}$ without degradation under air, and characterized by NMR, mass and elemental analysis. In addition. the structure of 1 was unambiguously established by single-crystal X-ray diffraction analysis.

The crystal structure and packing diagram of 1 is presented in Figure 1. Complex $\mathbf{1}$ in crystal structure exhibits only facial configuration with distorted octahedral geometry around Ir atom, as shown in Figure I. The dihedral angle between the phenyl and pyridine rings in $1\left(12.51^{\circ}\right)$ are larger than that of other mononuclear $\operatorname{lr}(p p y)_{3}$ derivatives. This fact renders non co-planar geometry and diminution of $\pi$-orbitals overlaps between phenyl and pyridine ring. The $\mathrm{I} r-\mathrm{C}$ bond length of $2.01 \mathrm{l}$ (3) $\AA$ are within the range reported for other complexes with the $\operatorname{lr}(p p y)$ ? moiety (1.97(2)-2.13(6) $\AA){ }^{9}$ however, they are close to values reported for the $(t p)_{2} \operatorname{lr}(\mu-\mathrm{Cl})_{2} \operatorname{lr}(t p y)_{2}$, and other $f a c-\operatorname{Ir}(p p y)_{3}$ derivatives. ${ }^{10}$ The $\sigma$-donor $\mathrm{C}$ atoms in metalated $p p v$ ligand arrange tronsdisposition to dative $\mathrm{N}$ atoms in the adjacent ppy ring. The $\mathrm{r}-\mathrm{N}$ bond lengths (2.13I(6) $\AA$ ) observed in 1 are slightly longer than those of $\operatorname{Ir}(t p y)_{2}(\mathrm{acac})(t p y-p$-toly-2-pyridine, acac - acetylacetonato) $(2.040(5) \AA)$ and $\operatorname{Ir}(p p y)_{2}(\mathrm{acac})$ 
(2.010(9) $\AA){ }^{t /}$ These observed elongations imply a stronger trans influence of phenyl groups relative to pyridyl groups. In crystal packing, complex 1 displays an overlap of the pyridine rings between two adjacent molecules (Fig. I). The
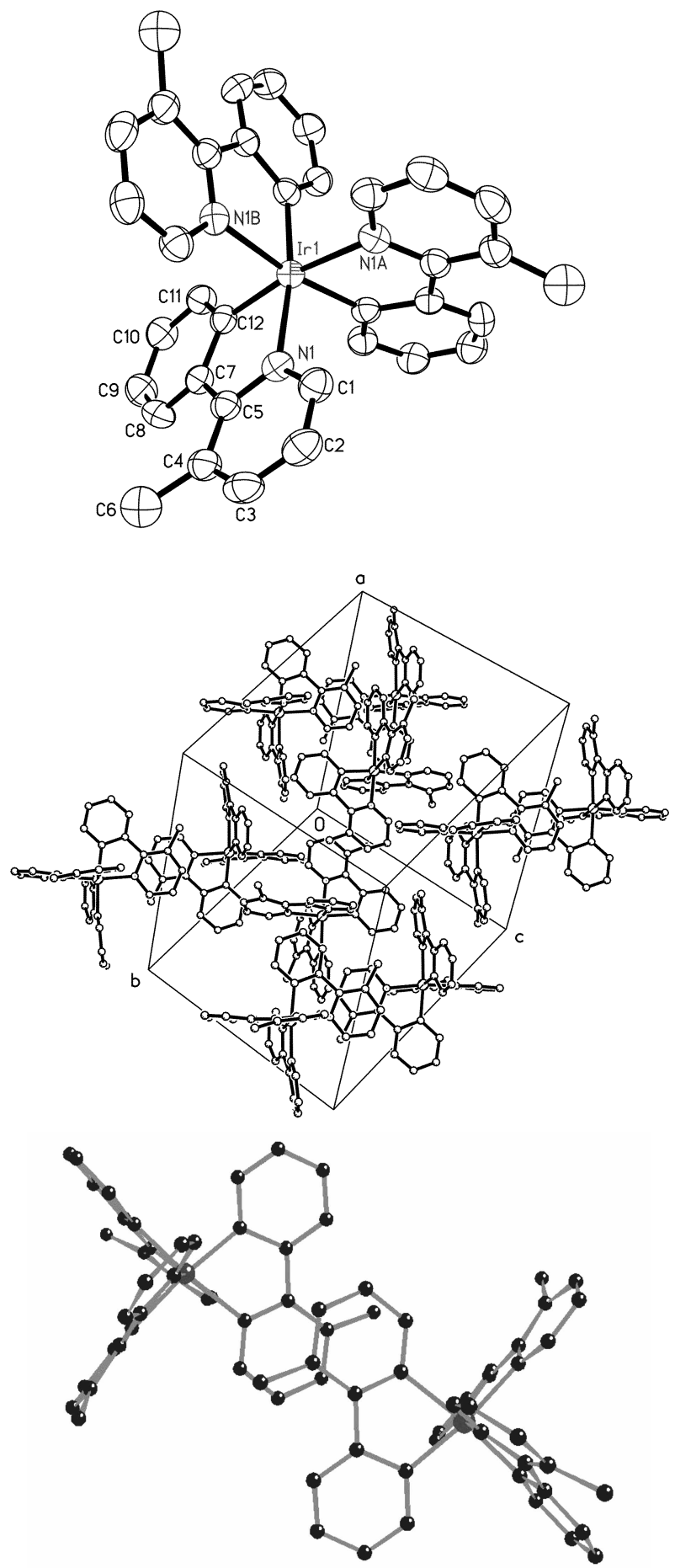

Figure 1. Top: Molecular structure of I with atom labeling schemes and $50 \%$ thermal ellipsoids. All hydrogen atoms are omitted for clarity. Middk : Packing diagram in a unit cell. Bottom: Diagram of 1 wo adjacent molecules in a unit cell. Selected bond lengths $[\dot{\Lambda}]$ and angles $\left[^{\circ}\right]$ : Ir 11$)-C(12) 2.011(3), \operatorname{Ir}(1)-\mathrm{V}(1) 2.131$ (3): $((12)-\operatorname{lr}(1)-C(12 \AA) 95.97$ (12). C(12B)- $\operatorname{lr}(1)-\mathrm{N}(1) 91.39$ (11). $\mathrm{N}(\mathrm{I})-\operatorname{Ir}(\mathrm{I})-\mathrm{N}(1 \mathrm{~A}) 95.22(\mathrm{I})$ and $\mathrm{C}(12)-\operatorname{lr}(\mathrm{I})-\mathrm{N}(\mathrm{IA}) 170.99$ (II). shortest separation distance between two adjacent pyridy] groups is approximately $3.408 \AA$, indicating that there are $\pi-\pi$ stacking interactions in a crystal lattice. This result suggests that. if complex 1 is used as a dopant in OLEDs. self-quenching will occur readily at high doping levels due to intermolecular interactions.

To understand the nature of luminescence exhibited by $\mathbf{l}$, DF[ calculation was conducted employing a Gaussian98" package. The geometric parameters in the calculations were employed from crystal structure data. The experimental value of the dihedral angle between phenyl and pyridyl groups, which is obtained by $\mathrm{X}$-ray structure, is comparable to the calculated value $\left(9^{\circ}\right)$. A diagram showing the electron dispersion of HOMO and LUMO for $\mathbf{l}$ is depicted in Figure 2. As shown Figure 2, the HOMO of 1 involves $\pi$ orbital localized on the phenyl groups with the contribution of
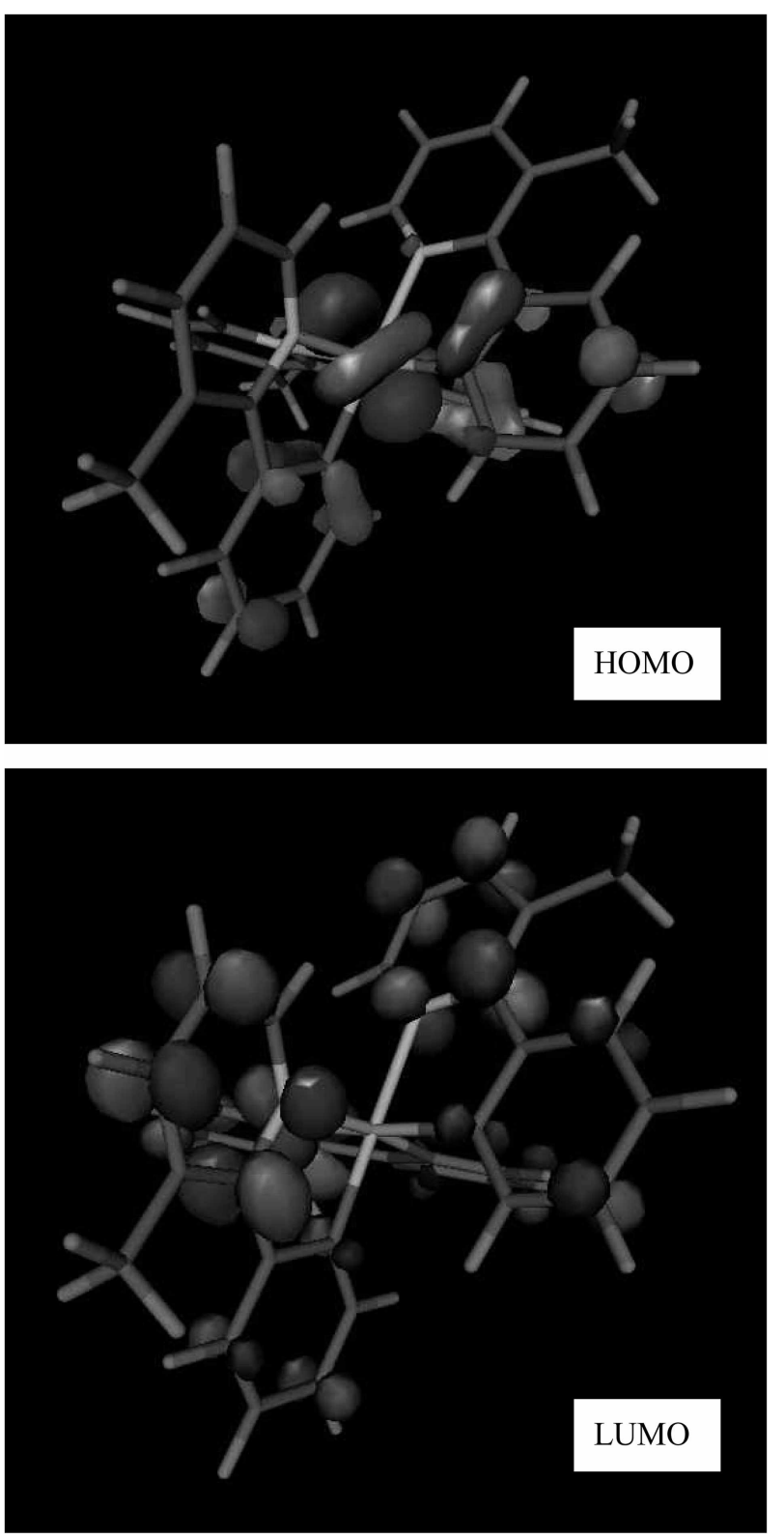

Figure 2. Diagrams showing the dispersion of electron density for 1 in HOMO and LUMO levils. 
Table 1. Calculated HOMO/LUMO energies and band gaps for complex 1 in ground state using DFT (Density Functional Theory)

\begin{tabular}{cccc}
\hline Complex & HOMO $(\mathrm{eV})$ & LUMO $(\mathrm{eV})$ & Band gap \\
\hline$f a c-\operatorname{Ir}(\mathrm{ppy})_{3}$ & -4.85 & -1.21 & 3.64 \\
$f a c-\operatorname{Ir}(\operatorname{mpp})_{3}$ & -4.75 & -1.09 & 3.66 \\
\hline
\end{tabular}

$\operatorname{Ir}\left(\mathrm{d}_{z}{ }^{2}\right)$. However, the LUMO is doninated by the $\pi^{*}$ orbitals of pyridine rings. It is noteworthy that the significant contributions of both Ir metal $\left(\mathrm{d}_{z^{3}}{ }^{3}\right)$ and phenyl $\left(\pi^{*}\right)$ orbitals in the LUMO level were not observed. The band gap between HOMO $(-4.75 \mathrm{eV})$ and LUMO $(-1.09 \mathrm{eV})$ is 3.66 eV. As shown in Table 1, complex 1 exhibits a larger band gap and a higher HOMO level $(\sim 0.1 \mathrm{eV})$ relative to $\operatorname{Ir}\left(p p y_{3}\right.$ (band gap: $3.64 \mathrm{eV}$. energy level of HOMO: $-4.85 \mathrm{eV}$ ). ${ }^{8.13}$ The excitation energies for low-lying singlet and triplet states of 1 were obtained from Tume-dependent DFT (TDDFT) calculations. Excitation energies for a singlet $\left(S_{1}\right)$ and a triplet $\left(\mathrm{T}_{1}\right)$ state are $2.9001 \mathrm{eV}(427.52 \mathrm{~nm})$ and $2.6197 \mathrm{eV}$ $(473.27 \mathrm{~lm})$, respectively. Experimentally, we observed that ${ }^{1} \mathrm{MLCT}$ (metal-to-ligand charge transfer) and ${ }^{3} \mathrm{MLCT}$ bands of $1 \mathrm{in}$ UV/Vis spectrum were at $430 \mathrm{~cm}$ and $475 \mathrm{~nm}$. respectively. ${ }^{13}$ Therefore, these results are in agreement with literature values. According to this results. both calculated the $S_{1}$ and $T_{1}$ excited states could be assigned as MLCT states based on the strong $5 \mathrm{~d}$ component of the occupied orbitals and the mostly ligand $\pi^{*}(\mathrm{py})$ virtual orbitals. ${ }^{1.13}$ These DFT calculations provide evidence that the luminescence observed in complex 1 originates from the Ir perturbed ligand-centered transitions.

In conclusions, our prelininary investigations on photoelectroluminescent properties of methyl-substituted $\operatorname{Ir}(p p y)_{3}$ derivatives, other complexes show very similar luminescent properties to $\operatorname{Ir}(p p v)_{3}$. However. complex 1 exhibits shorter life times in excited states and higher quantum efficiency than those of $\operatorname{Ir}(p p v)_{3}$ as well as other methylated complexes. ${ }^{1+}$ Based on these observations, we suggest that the nature of excite states in the $\operatorname{Ir}\left(p p y^{\prime}\right)_{3}$ sy'stem are significantly affected by the chemical variants introduced at $\mathrm{N}-3$ or $\mathrm{C}-6$ positions in the ppy' ring. Further sy'stematic investigations on the effects of substituents and positions in the $p p y^{\prime}$ ring are currently being conducted.

\section{Experimental Section}

Synthesis. Complex 1 was synthesized by previous procedures reported in literature ${ }^{8.15}$

Computations. Computations on the electronic ground state of 1 were performed using Becke's 3 parameter density functional in combination with the nonlocal correlation functional of Lee. Yang and Parr (B3LYP) ${ }^{16} 6-31 G(d)$ basis sets were employed for the ligand and a relativistic effective core potential of Los Alamos and Double- $\zeta$ basis sets were employed for the Ir(LANL2DZ) ${ }^{12}$ The ground state geometries were fully optimized at the B3LYP level and timedependent-DFT(TDDFT) ${ }^{17}$ calculations were formed to obtain the vertical singlet and triplet excitation energies. All computations were performed using Gaussian-98 package installed on 8 node Pentium 4 cluster along the Linda parallel software.

X-ray Crystallographic Analysis. Suitable crystals of 1 were obtained from slow vapor diffusion of toluene/benzene/ hexane (2:1:1) into solution of 1 in $\mathrm{CH}_{2} \mathrm{Cl}_{2}$. The cry stals of 1 was attached to glass fibers and mounted on a Bruker SMART diffractometer equipped with a graphite monocluromated Mo $\mathrm{K} \alpha(\lambda=0.71073 \AA)$ radiation, operating at $50 \mathrm{kV}$ and $30 \mathrm{~mA}$ and a CCD detector. 45 frames of twodimensional diffraction images were collected and processed to obtain the cell parameters and orientation matrix. All data collections were perfonmed at $298 \mathrm{~K}$. The data collection $2 \theta$ ranges are $3 \cdot 1-56.6^{\circ}$. No significant decay was observed during data collection. The raw data were processed to give structure factors using the SAINT program. Each structure was solved by direction methods and refined by full matrix least squares against $F^{3}$ for all data using SHELXTL software (version 5.10). ${ }^{18}$ All non-hydrogen atoms in 1 were anisotropically refined. All other hydrogen atoms were included in the calculated positions and their contributions in structural factor calculations were included. The compounds 1 cocrystallize with a benzene in asymmetric unit and crystal system is the trigonal and space groups $\mathrm{P}-3 \mathrm{Cl}$. The refine atomic coordinates and anisotropic thermal parameters are deposited in CCDC (The Cambridge Crystallographic Data Centre). Benzene disordered with each occupancy of one was not modeled successfully. Therefore. hydrogen atoms in benzene were not included in the calculated positions. Crystallographic data for the structure reported here have been deposited with the Cambridge Crystallographic Data Centre (Deposition No. CCDC-215084). The data can be obtained free of charge via htp : и'и'исcdc.com ac.uk pent catreqcatreq.cgi (or from the CCDC. 12 Union Road, Cambridge CB2 IEZ, UK: fax: +44 1223 336033: e-mail: deposita.ccdc.cum. (a. uk).

Crystal data: $\mathrm{C}_{4} \mathrm{H}_{31 \mathrm{ij}} \mathrm{N}_{3} \mathrm{Ir}, M=768.89$. Trigonal, Space group P-3cl. $a=15.184(2) \AA . b=15.184(2) \AA, c=15.739$ (3) $A, V=3142.4(9) A^{3}, Z=4, D_{c}=1.625 \mathrm{~g} / \mathrm{cm}^{3}, \mu=4.285$ $\mathrm{mm}^{-1}, F(000)=1520, T=293(2) \mathrm{K}$. Refinement of 139 parameters on 2584 independent reflections out of 21127 measured reflections $\left(R_{\text {int }}=0.0270\right)$ led to $R_{1}=0.0189, w R_{2}$ $=0.0460$ and $\mathrm{GOF}=0.963$.

Acknowledgement. This work was supported by Korea Research Foundation Grant (KRF-2002-050-C00010). Dr. Kang thanks for Res. Prof. Ki-Min Park's helpful discussion and Dr. Ruiyao Wang at Queen's university for the instrumentation support (X-ray crystallography).

\section{References}

1. (a) Baldo. M. A.: Thompsont. M. E.: Forrest. S. R. Fanue 2000. 403. 750-753. (b) Baldo. M. A.: Lamanshy. S.: Burrows. P. E.: Thompson. M. E.: Forrest. S. R. Appl Phys Lett 1999. 75. 4-6. (c) Adachi, C: Baldo, M. A.: Forrest. S. R:; Thompson. M. E. Appl. Phys. Lett 2000. 77. 904-906. (d) Gao, R.: Ho, D. G.: Hernandez. H: Selke. M.: Murphy. D.: Djurovich. P. I.: 
Thompson. M. E. J. Am. Chem. Soc. 2002, 124. 14828 -14829. (e) Lamansky. S.: Djurovich. P. I.: Murphy. D.: Abdel-Razzaq. F.: Lee. H.-E.: Adachi. C.: Burrows. P. E.: Forrest. S. R.: Thompson. M. E. J. Am. Chem. Soc. 2001. 123. 4304-4312 (f) Lamansky. S.: Kwong. R. C: Nugent, M.: Djurotich. P. I.: Thompson. M. E. Org. Elechochem. 2001, 2. 53-62. (g) Ikai. M: Tokito, S: Sakamoto, Y: Suzukj, T.: Taga. Y. Appl. Phns Lett 2001, 79. $156-$ 158. (h) Adachi. C.: Baldo. M. A.: Forrest. S. R.: Thompson. M. E. J. Appl. Plws. 2001. 90. 5048-5051. (i) Yang. M.J.: Tsutsui. T. Jph. J. Appt. Phvs. 2000. 39. L828-L829. (j) Vander Donckt. E.: Camerman, B: Hendrick. F: Hente. R.: Vandeloise, R. Bull Soc. Chim. Belg. 1994, 103, 207-211. (k) Amao, Y; Ishikawa, Y: Okura, I. Anal. Chim .Acta 2001. 45, 177-182. (1) Balzani, V: Juris. A.: Venturi. M.: Campagna. S.: Serroni. S. Chem. Rer. 1996. 96. 759-834 (m) Kim. S. M.: Kim. S.-J.: Shin. D.-M.: Kim. Y. K.: Ha. Y. Bull Korean Chem. Soc. 2001. 7. 743-747. (n) Lee. D. N.: Park. H. I: Lee, D. H.: Lee. S. W.: Park. S. J: Kim. B. H.: Lee. W. Y. Bull. Korean Chem. Soc. 2002, 1, 13-14.

2. (a) OBrien. D. F.: Baldo, M. A.: Thompson, M. E.: Forrest. S. R. Appl. Phys. Lett 1999. 74. 442-444. (b) Duan. J.-P.: Sun. P.-P.: Cheng. C.-H. Adt: Afater 2003. 15. 224-228. (c) Xie. H. Z.: Liu. M. W.: Wang. O. Y.: Zhang. X. H.: Lee. C. S.: Hung. L. S.: Lee. S. T: Teng. P. F.: Kwong. H. L.: Zheng, H.: Che, C. M. Adr hater. 2001, 13. 1245-1248. (d) Noh. Y.-Y.: Lee, C.-L.; Kim, J-J Y Yase. K. $J$. Chem. Phn 2003. 118. 2853-2864. (e) Wang. Y.: Herron, N: Grushin. V. V.: LeCloux. D.: Petrov. V. Appl. Phys. Lett. 2001. 79. 449-451.

3. (a) Adachi. C.: Kwong. R. C.: Djurovich. P: Adamovich. V: Baldo, M. A; Thompson. M. E; Forrest, S. R. Appl. Phus. Lett. 2001, 79. 2082-2084. (b) Kawanulura, Y.: Yanagida, S.: Forrest. S. R. J. Appl. Phys. 2002. 92. 87-93. (c) Chen. F.C.: Yang. Y: Thompson. M. E.: Kido. J. Appl. Phys. Lett. 2002. $80.2308-2310$. (d) Lamanshy. S.: Thompson. M. E.: Adamovich. V: Djurovich. P. I.: Adachi. C.: Baldo. M. A.: Forrest. S. R.: Raymond. K. Patent No. LS2002182H11,2002

4. (a) Allevne, B. D.; Adamovich. V.: Brooks. J.: Djurovich. P. I.: Thompson, M. E. 22t ACS National Heetmg. US. INOR-204. 2002. (b) Thompson. M. E.: Forrest. S. R. IMAD (proceeding of the $1^{\text {it }}$ International Meeting on Information Display). 2001. 859861. (c) Grushin. V. V:: Herron. N.: LeCloux. D. D.: Marshall. W. I.: Petrov. V. A. Wang. Y. Chent Conmun. 2001. 1494-1495. (d) Lamansky, S.: Djurovich. P.: Murphy: D: Abdel-Razzaq. F.: Kwong, R.: Tsyba. I.: Bortz. M: Mui, B.: Bau. R: Thompson. M. E. Whorg. Chem. 2001. 40.1704-1711.

5. Sapochak. L. S.: Padmaperuma. A.: Washton. N.: Endrino. F.: Schmett. G. T: Marshall. J.: Fogarty. D.: Burrows. P. E.: Forrest. S. R. J.Am. Chem Soc 2001. 123,6300-6307.
6. Recent Review: (a) Hassan. J; Sevignon, M: Gozzi. C.; Schulz. E.: Lemaire. M. Chem. Rev 2012. 102. 1359-1469. (b) Suzuki. A. J. Onganomet. Chent 1999.576. 147-168.

7. (a) Ichimura. K.: Kobayashi. T.: King. K. A.: Watts. R. T. J. Phns Chent 1987. 91. 6104-6106. (b) King. K. A.; Spellane, P. J. Watts, R. J. J. Am. Chem. Soc. 1985. 107, 1431-1432.

8. (a) Recent report : Tamavo, A. B.: Allevne. B. D.: Djurovich, P. I.: Lamansky. S.: Tsyba. I.: Ho. N. N.: Baut. R.: Thompsont. M. E. $J$. Ant Chent Soc. 2003. 125.7377-7387. (b) Dedeian. K.: Djurovich. P. I.: Garces. F. O.: Carlson1. G.: Watts. R. T. Inorg Chent. 1991. 30. 1685-1687, (c) Colombo. M. G.: Brunold, T. C.: Riedener. T.: Guedel. H. U.: Fortsch. M.: Buergi. H.-B. Inorg. Chem. 1994. 33. $545-550$

9. (a) Urban. R.: Krämer. R.: Mihan1. S.: Polbon. K.: Wagner. B.: Beck. W. J. Organonet. Chent 1996. 517. 191-200 (b) Neve. F.: Crispini. A. Eur. J. Inorg Chent 2000. 1039-1043.

10. Garces. F. O.: Dedeian, K.: Keder. N. L: Watts, R. J. Acta Crustallog: 1993. C49, $1117-1120$

11. Frisch. M. J:- Trucks. G. W: Schlegel, H. B.: Scuseria. G. E: Robb. M. A.: Cheeseman. I. R.: Zakizewski. V. G.: Montgomery. J. A.. ITr: Stratmant11. F. E.: Burant. J. C.: Dapprich. S. Millamn. .T. M.: Daniels. A. D.: Kuditı. K. N.: Straitr. M. C.: Farkas. O.: Tomasi, J.: Barone, V: Cossi, M.: Cammi, R.: Mennucci, B.: Pomelli. C.: Adamo. C.; Clifford. S: Ochterski, J.: Petersson. G. A.; Avala. P. Y.: Cui, Q; Morokuma. K.: Malick. D. K: Rabuck. A. D.: Raghavachari. K.: Foresman. J. B.: Cioslowski. T.: Ottiz. .T. V.: Stefanov. B. B.: Liu. G.: Liashetrko. A.: Piskorz. P.: Komaromi. I.: Gomperts. R.: Martin. R. L.: Fox. D. J.: Keith. T.: Al-Laham. M. A.; Peng, C. Y.: Nanayaktiara. A.: Gonzalez, C.: Challacombe, M.: Gill. P. M. W.: Johnson. B.: Chen, W., Wong, M. W. Andres, J. L.: Head-Gordon, M:- Replogle. E. S.; Pople. J. A. Gaussian 98. Revision A. 7: Gaussianl. Inc:: Pittsburgh. PA. 1998

12. Hay. P. T. J. Phws. Chem . A 2002. 106. 1634-1641

13. Jung. S. O.: Kwonl. S.-K. $22 t^{\text {fi }}$ ACS National Meeting. Boston. US. INOR-95. 2002.

14. The systematic investigation on effects of methyl-substituent depending on positions of ppy ring will be published elsewhere soon.

15. Das. R. R.: Lee. C.-L.: Noh. Y.-Y.: Kim. Т.-T. Optical Material 2002. 21. $143-146$.

16. (a) Becke. A. D. J. Chem. Phws 1993. 98. 5618-5652. (b) Lee, C.; Yang. W: Parr, R. G. Phys. Rev B 1988, 37, 785-789.

17. Jarmorski, C.: Casida. M. E.: Salahub. D. R. J. Chem. Phys. 1996. 104. $5134-5147$

18. SHELITL NT Crnstal Structure Andhsis Package, Version 5.10. Bruker AXS: Analytical X-ray System. Madison. WI. 1999. 